
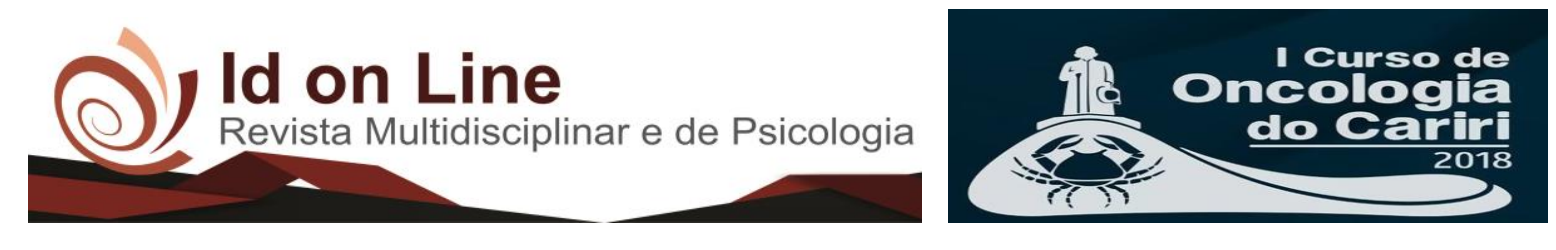

Resumo

\title{
TRANSPLANTE AUTÓLOGO NO TRATAMENTO DE MIELOMA MÚLTIPLO
}

\author{
Maria Iara Alves Araújo ${ }^{1}$, Brenda Lacerda da Silva ${ }^{1}$, Francisco Allyson Lopes Xavier'I, Itamar Alves Araújol.
}

Introdução: O mieloma múltiplo é uma patologia maligna de células asmocitárias incurável mesmo com as terapias atualmente disponíveis. O transplante de célulastronco hematopoiéticas está incluso na estratégia terapêutica para a maioria dos pacientes. Além de ser um avanço na terapia do mieloma múltiplo, o transplante autólogo é um procedimento viável e seguro. Objetivo: Explanar sobre o transplante autólogo como tratamento de mieloma múltiplo. Método: Revisão sistemática baseada em matérias publicadas em artigos disponíveis nas bases de dados SciELO e LILACS. Os descritores usados na busca (em português e inglês) foram: mieloma múltiplo, transplante autólogo e tratamentos de mieloma múltiplo; sendo pesquisados no DeCS. Os critérios de inclusão foram: estudos sobre o mieloma múltiplo, tipos de tratamento e transplante autólogo como terapia para mieloma múltiplo; e os de exclusão: matérias direcionadas para transplante alogênico e estudos que não fossem com humanos. Ademais, artigos publicados, independentemente da data, foram relevantes para a extração de dados. Foram encontrados 86 artigos. Desse total, foram apurados com base nos critérios de inclusão e exclusão. Resultado: Com base nas informações apuradas, constata-se que existem várias terapias para o paciente com mieloma múltiplo. Ademais, o transplante autólogo obteve um avanço notável na terapia introdutória de quimioterapia de alta, com elevada taxa de respostas completas e sobrevida global média maior do que com a quimioterapia convencional. Desse modo, o transplante serve para intensificar o tratamento e melhorar o bem-estar do paciente. Portanto, o transplante autólogo é uma opção para pacientes com menos de 65 anos de idade, em condições fisiológicas adequadas; mas, para casos em que a doença volta mesmo após o tratamento quimioterápico não é mais uma opção.

Palavras-chave: mieloma múltiplo, tratamentos, transplante autólogo.

\footnotetext{
${ }^{1}$ Discente da Faculdade de Medicina Estácio de Juazeiro do Norte; Autor correspondente: iara_aaraujo@hotmail.com

34 Id on Line Rev. Mult. Psic. V.12, N. 40. 2018 - ISSN 1981-1179 EDIÇÃO ESPECIAL: I CURSO DE ONCOLOGIA DO CARIRI / II JORNADA DE PESQUISA QUANTI-QUALITATIVA EM ONCOLOGIA. JUAZEIRO DO NORTE, 05 A 10 DE MARÇO DE 2018. Edição eletrônica em http://idonline.emnuvens.com.br/id
} 